\title{
Impact of live tubificid worms on the growth and survival of Heteropneustes fossilis (Bloch, 1794) reared in tanks
}

\author{
M. J. Hossain, A. Hossain, S. C. Mandal and M. S. Rahman* \\ Department of Fisheries, Faculty of Biological Sciences, University of Dhaka, Dhaka 1000, Bangladesh
}

\begin{abstract}
An experiment was conducted on growth, survival and flesh quality of fingerlings of stinging catfish, Heteropneustes fossilis (Bloch, 1794) were evaluated using three types of feeds namely live tubificid worm, tubificid powder and commercial pellet feed. Three feeds were used in three treatments where Treatment- $\mathrm{T}_{1}$ with pellet feed (control), Treatment- $\mathrm{T}_{2}$ with tubificid powder and Treatment- $\mathrm{T}_{3}$ having live tubificid worms. Twenty fingerlings $(8.04 \pm 0.01 \mathrm{~g})$ were released in each $50 \mathrm{~L}$ tank for 45 days rearing. The fishes were fed twice a day at $10 \%$ of body weight for first 15 days and that of $8 \%$ per day for the next 30 days. Sampling was conducted fortnightly. Significant higher mean weight $48.53 \pm 1.13 \mathrm{~g}$ was observed in stinging catfish at the 45 th day fed with live tubificid worms than those of others (P<0.05). The highest survival rate was $83.33 \pm 4.41 \%$, average daily gain $0.90 \pm 0.03 \mathrm{~g} \mathrm{day}^{-1}$, specific growth rate $3.99 \pm 0.05 \%$, food conversion ratio $1.65 \pm$ 0.10 and protein content $17.48 \pm 0.28 \%$ were found at the 45 th day of treatment $\mathrm{T} 3$ when live tubificid worms were used as feed. Live tubificid worms can be used as a good alternative to commercial feed in rearing of stinging catfish.
\end{abstract}

Keywords: Live feed, Tubificid worms, Stinging catfish, Growth performance, Survivability

\section{Introduction}

Stinging catfish (Heteropneustes fossilis) is a very popular, tasty and high valued fish in Bangladesh. Due to high nutritive values, this fish is recommended for the diet of sick and convalescent patients. Presently, stinging catfish is declared as one of the threatened fish in Bangladesh (IUCN, 2000). Considering its status it is essential to develop a suitable culture technique in Bangladesh. However, very little published literature are available on growth and production of stinging catfish in pond, cistern and net cages in Bangladesh (Haque et al., 1988; Khan et al., 2003; Narejo et al., 2005 and Kohinoor et al., 2012). This is an excellent fish for culture in derelict water bodies as it is able to live in poorly oxygenated water due to its capacity to exchange via accessory respiratory organ (Singh and Hughes, 1971). It can be cultured very densely, in extensive and semi-extensive conditions and on a large scale in industrialized sectors and the yield per hectare are several time higher in comparison to carp species (Dehadrai et al., 1985). In Bangladesh, commercial feed is used in rearing shing and the farmers face suffocation problems in dry season causing reduced water depth and increased water turbidity. These problems can be reduced by using live feeds. Tubificid worms (Oligochaeta, Tubificidae) are used as live feed in aquaculture which plays vital role in the rearing process of catfish larvae (Hossain et al., 2012). These worms were also used in commercial fish culture in the former Union of the Soviet Socialist Republic (Lietz, 1987), and now they are being used all over the world, including Bangladesh. However, due to climate change, stinging catfish stock is greatly affected because of decreasing natural habitat in the least developed country like Bangladesh. Although many countries have taken initiatives to tackle this adverse condition but Bangladesh is far away from the path. So it is necessary to open up a new culture technique of the improvement of stinging catfish production by using live feed like tubificid worms in Bangladesh.

The culture technique of carp species is very developed in our country but shingi culture is not done in proper systematic way. Very little work has been carried out on shingi culture in Bangladesh. Therefore, the present study was conducted to investigate the impact of three different feeds on the growth and survival of shingi.

*Corresponding author. e-mail: shamsur@du.ac.bd 


\section{Materials and methods}

Stinging catfish fingerlings $(8.04 \pm 0.01 \mathrm{~g})$ were collected from Mymensingh and transported to the Aquatic Laboratory of the Department of Fisheries, University of Dhaka in oxygenated polythene bags. Fingerlings were stocked in the rearing tanks after 7 days of conditioning. The experiment was designed as three treatments where treatment $1\left(\mathrm{~T}_{1}\right)$ : commercial pellet feed (Control), treatment 2 $\left(\mathrm{T}_{2}\right)$ : tubicid powder and treatment $3\left(\mathrm{~T}_{3}\right)$ : live tubificid worms with three replicates. Each of the aquariums was filled up with 50 litres pond water and each aquarium contained with 20 fingerlings and reared for 45 days. Continuous aeration was provided. Fish were fed twice a day (10:00 AM and 18:00 PM) at the rate of 10\% body weight for the first 15 days and $8 \%$ for next 30 days. Sampling was maintained at 15 days interval and weight $(\mathrm{g})$ was recorded for further analyses.

Data were collected during the rearing period for the purpose of determining growth parameters. Average daily gain (ADG), Specific growth rate (SGR) and Food conversion ratio (FCR) were determined following Chakraborty and Mirza (2008): ADG (g) = (mean final weight-mean initial weight $) /$ time interval (days); SGR $(\%)=($ Ln mean final weight - Ln mean initial weight)/time interval (days) $\times 100$; FCR $=$ Total diet fed $(\mathrm{kg}) /$ total wet weight gain $(\mathrm{kg})$. Survival rate $(\%)$ was measured by computing the death and lives fishes of the culture. Temperature $\left({ }^{\circ} \mathrm{C}\right)$, dissolved oxygen $\left(\mathrm{DO} ; \mathrm{mgL}^{-1}\right), \mathrm{pH}$ and conductivity were measured by using HACH®HQ11d meter. Turbidity of water was also calculated with spectrophotometer. Moisture and crude protein were determined by AOAC (1995) and Micro-Kjeldahl method.

Data were analyzed by using ANOVA followed by Tukey's HSD post hoc for multiple comparisons. The data were presented as mean \pm SEM and analyzed by using the statistical program IBM SPSS statistics version 20.0 with the level of significance at $\mathrm{p}<0.05$.

\section{Results and discussion}

Significantly higher weight $(48.53 \pm 1.13 \mathrm{~g})$ of fingerling was observed at the 45 th day in treatment $T_{3}$ fed with live tubificid worms than those of others while lower weight $28.97 \pm 0.24 \mathrm{~g}$ and $24.67 \pm 0.49 \mathrm{~g}$ were observed in the treatments $\mathrm{T}_{2}$ and $\mathrm{T}_{1}$, respectively $(\mathrm{P}<0.05$; Fig. 1$)$.

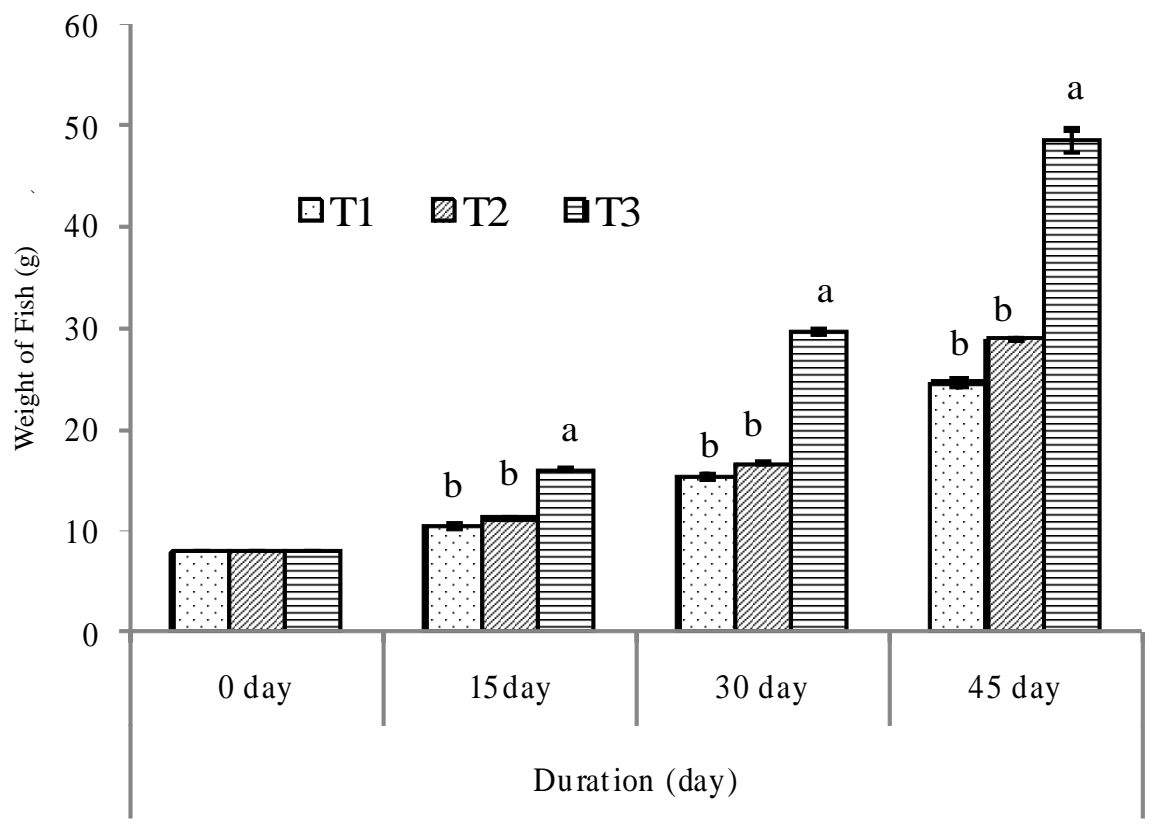

Fig. 1. Final weight (g) of stinging catfish fingerlings at 45days rearing period. Bars (Mean $\pm \mathrm{SEM}$ ) with different letters are significantly different within group (ANOVA, HSD; $\mathbf{p}<0.05$ ) 
Growth in terms of mean harvesting weight stinging catfish was higher in $T_{1}$ fed with live tubificid worm than that of others $(\mathrm{P}<0.05)$. Khan et al., (2003) observed the lower growth pattern on the production of catfish ( $\mathrm{H}$. fossilis) in earthen ponds using commercial feed.
For average daily gain (ADG), it is apparent that at the end of 45 days of rearing period, the highest value was achieved by fish at $\mathrm{T}_{3}$ fed with live tubificid worms. Average daily gain depends on the feed quality as well as environmental parameters particularly the acceptance of feed in culture con-

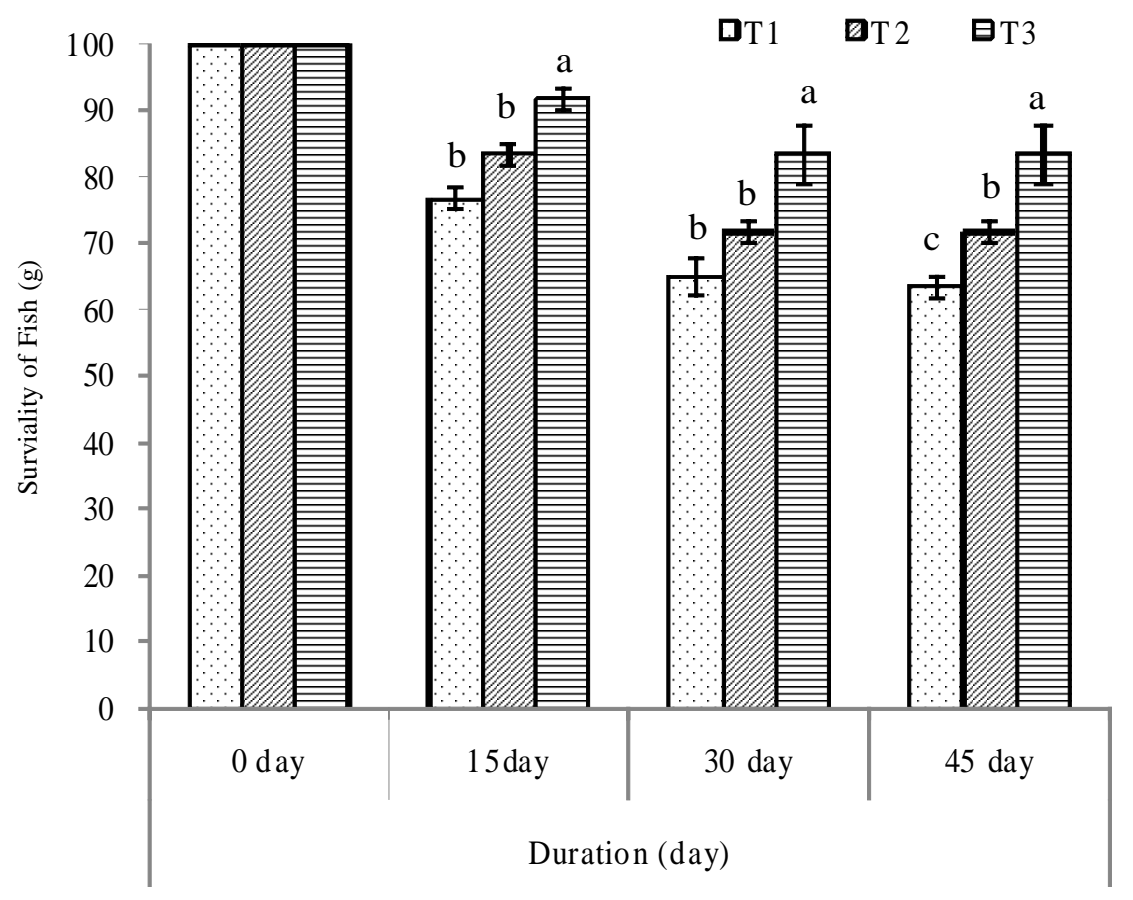

Fig. 2. Survival rate (\%) of stinging catfish fingerlings at 45 days rearing period. Bars (Mean \pm SEM) with different letters are significantly different within group (ANOVA, HSD; $\mathbf{p}<0.05$ )

The highest survival rate $83.33 \pm 4.41 \%$ was detected at the 45th day of treatment $\mathrm{T}_{1}$ fed with live tubificid worms $(\mathrm{P}<0.05$; Fig. 2). Significantly lower survival rate $(63.33 \pm$ $1.67 \%$ ) was observed at the 45 th day fed with commercial pellet feed; $\mathrm{T}_{1}(\mathrm{P}<0.05)$.

The better survival rate was observed in treatment $T_{3}$ because of using live feed and less turbidity of culture water. The percentage of survival as recorded in the present study was similar as reported by Kohinoor et al., (2012).

Significantly higher ADG $0.90 \pm 0.03 \mathrm{~g} \mathrm{day}^{-1}$ was detected at the 45th day fed with live tubificid worm than that of others $(\mathrm{P}<0.05$; Fig. 3). The lowest ADG $(0.2133 \pm 0.0120$ gday $^{-1}$ ) was recorded at the 15 th day while fed with commercial pellet feed $(\mathrm{P}<0.05)$. The ADG $0.9000 \pm 0.0265,0.4633$ \pm 0.0067 and $0.3900 \pm 0.0116$ gday $^{-1}$ of shing was evaluated at the 45 th day, respectively. dition. Chakraborty and Mirza (2008) recorded the highest $(0.29 \pm 0.0)$ ADG in their studies by using commercial feed. This finding is similar to the findings of our present studies when fed with commercial feed. However, significant higher ADG was estimated in our study for utilizing live tubificid worms.

SGR (\%) of stinging catfish fingerlings was significantly higher $(3.99 \pm 0.05)$ at the 45 th day feed with live tubificid worms than those of other treatments $\mathrm{T}_{1}(2.6667 \pm 0.1129)$ and $\mathrm{T}_{2}(2.8467 \pm 0.0186)(\mathrm{P}<0.05$; Fig. 4$)$.

SGR showed significant variations in all three treatment groups. SGR gradually decreased in the treatment $T_{3}$ with increasing culture period. This finding is similar to Medawar's (1945) conclusion depicting "the specific growth rate declines more and more slowly as the organism increases in age" in various conditions. 


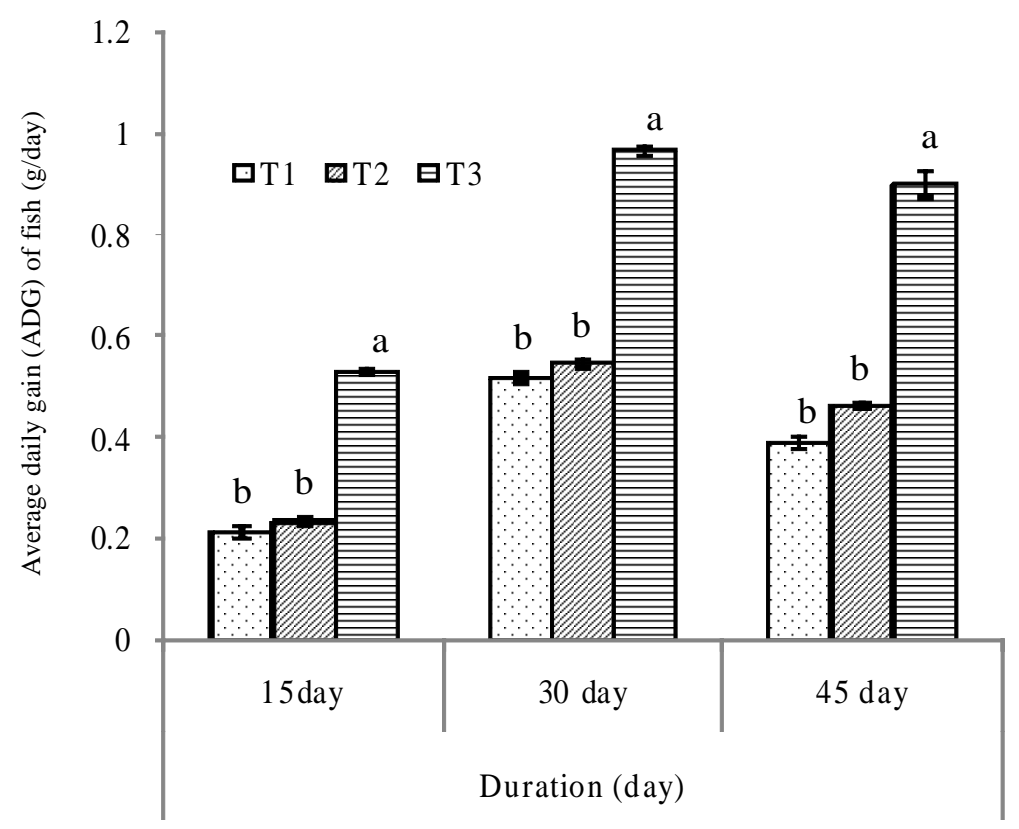

Fig. 3. Average Daily Gain of stinging catfish at 45 days rearing period. Bars (Mean \pm SEM) with different letters are significantly different within group (ANOVA, HSD; $\mathbf{p}<0.05$ )

Significant lower FCR $1.65 \pm 0.10$ was observed in the treatment $\mathrm{T}_{3}$ at the 45 th day when fed with live tubificid worms $(\mathrm{P}<0.05$; Fig. 5). The higher FCR (2.58 \pm 0.1762$)$ and $(2.18 \pm$ 0.0829 ) were observed at the 45 thday of treatments $T_{1}$ and $\mathrm{T}_{2}$, respectively.
Significant difference of FCR was evaluated in stinging catfish in $\mathrm{T}_{3}$ which might be because of feeding with live tubificid worms. Akand et al., (1989) recorded FCR values 2.0 to 2.7 in case of shing fingerlings having commercial pellet

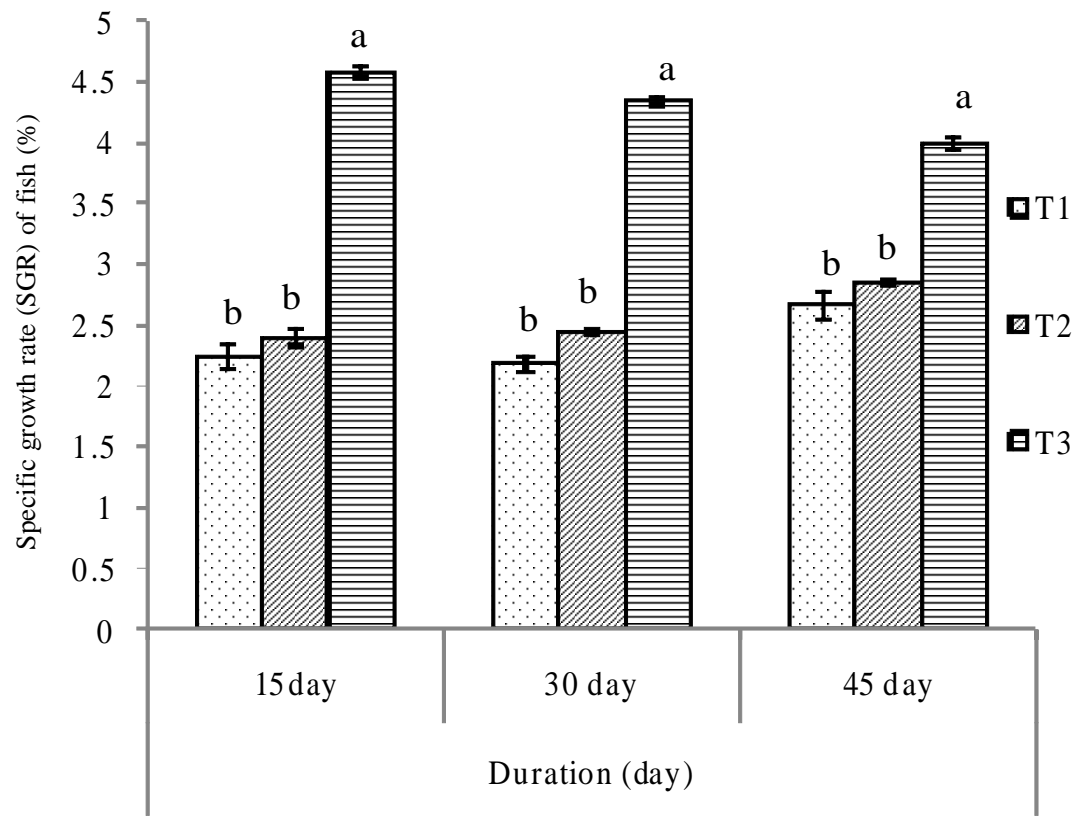

Fig. 4. Specific Growth Rate $(\%)$ of stinging catfish fingerlings at the 45 days rearing period. Bars $(M e a n \pm$ SEM) with different letters are significantly different within group (ANOVA, HSD; $\mathbf{p}<0.05$ ) 


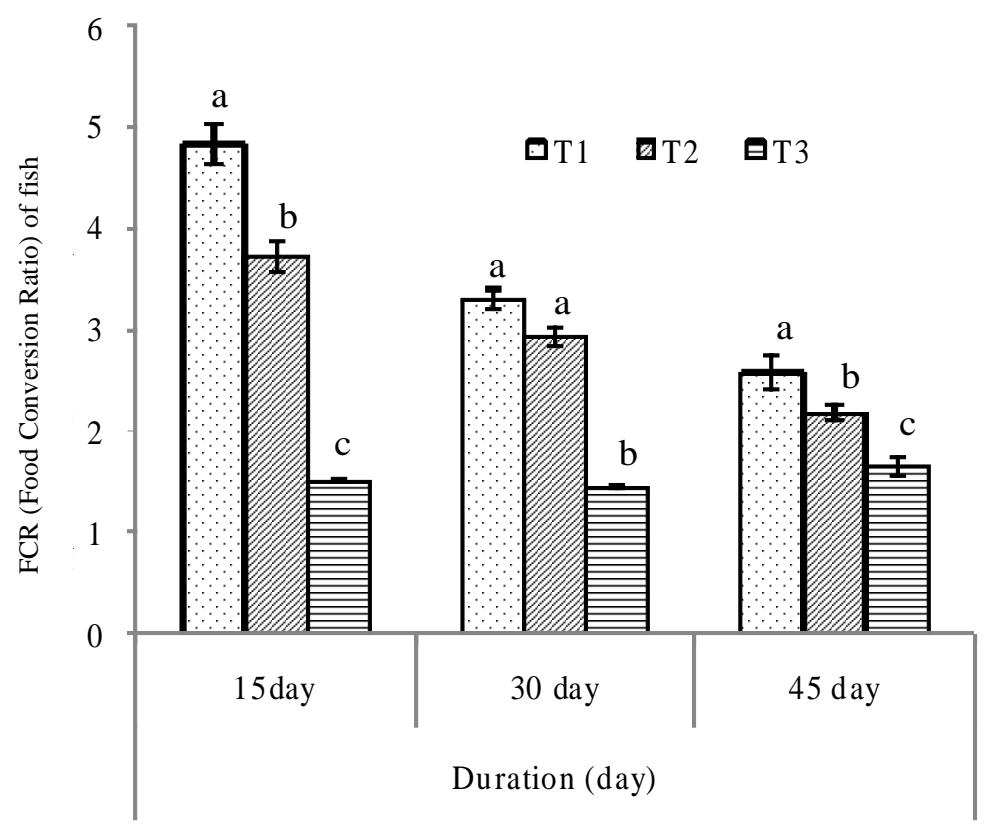

Fig. 5. Feed Conversion Ratio of stinging catfish fingerlings at the 45 days of rearing period. Bars (Mean \pm SEM) with different letters are significantly different within group (ANOVA, HSD; p<0.05)

feeds. FCR detected in the present study strongly admits the findings of Akand et al., (1989) for commercial pellet feed. Significantly lower values $(0.042 \pm 0.001$ FTU) of water tur. bidity in stinging catfish culture water was predicted at the 45thday when fed with live tubificid worms ( $>>0.05$; Fig. 6). Significantly higher value $(0.145 \pm 0.003)$ of water turbidity in

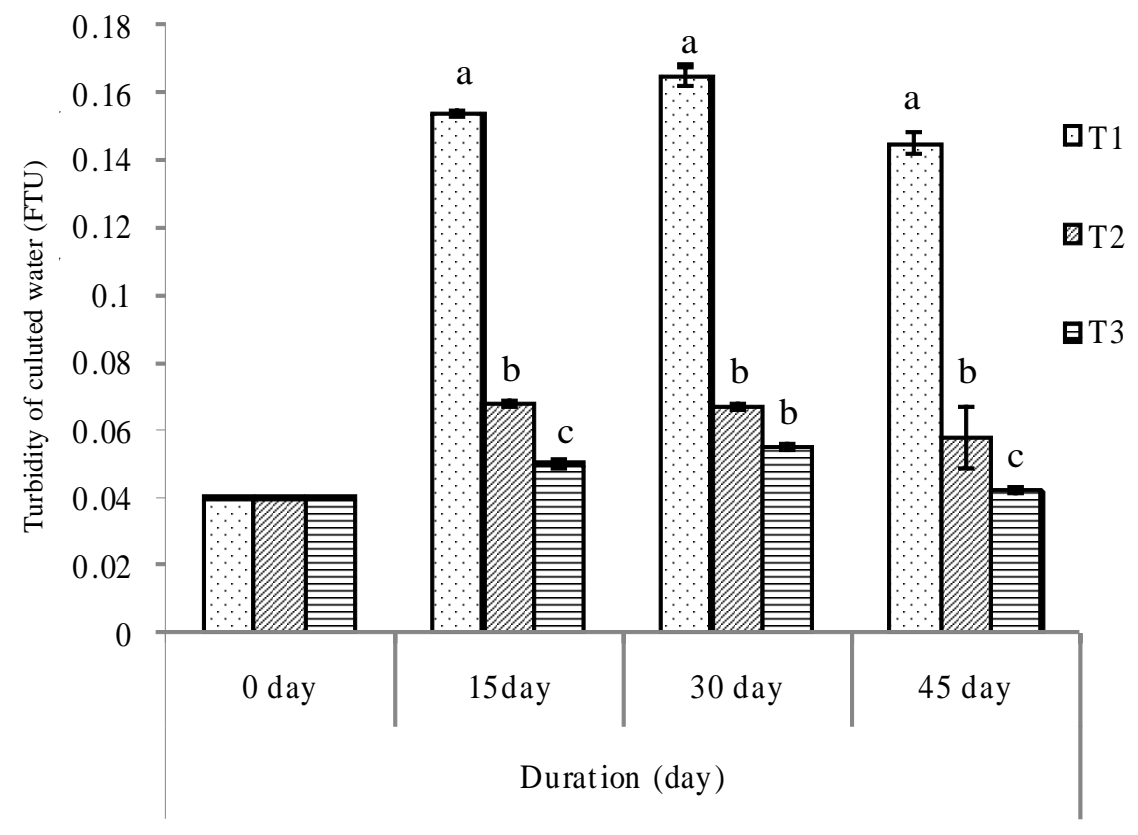

Fig. 6. Turbidity (FTU) in water of stinging catfish fingerlings at 45days rearing period. Bars (Mean \pm SEM) with different letters are significantly different within durations (ANOVA, HSD; p<0.05) 
stinging catfish in culture water was estimated at the 45 thday fed with commercial pellet feed $(\mathrm{P}<0.05)$.

The water turbidity is very important environmental factors in rearing shing. According to farmers (personal communication) of the Mymensingh areas, the survival of shing mostly depends on the turbidity of culture water. Suffocation is the main problem of smooth shing culture in pond condition. If it is possible to reduce the turbidity of culture water, it could be beneficial to further farming.

The range of water temperature, $\mathrm{pH}, \mathrm{DO}$ and conductivity was $25.80 \pm 0.03$ to $28.40 \pm 0.09{ }^{\circ} \mathrm{C}, 6.00 \pm 0.03$ to $6.40 \pm 0.06$, $4.00 \pm 0.33$ to $6.10 \pm 0.16 \mathrm{mgL}^{-1}$ and $375.00 \pm 0.00$ to 566.67 \pm 11.79 of the whole culture period (45days) in different treatments, respectively. Mollah (1985) reported water quality parameters (temperature; 26.06 to $31.97^{\circ} \mathrm{C}$, DO; 6.5 to $8.4 \mathrm{mg} / \mathrm{L}, \mathrm{pH} ; 6.5-9.0)$ that are suitable for stinging catfish culture. Conductivity was also recorded in suitable ranges.
Our results comply with the previous described results. The conductivity of the present study also appears suitable for shing culture.

In fig.7, negligible higher moisture content $(76.45 \pm 1.01)$ was evaluated in the treatment $T_{1}$ than those of others $\left(T_{2}\right.$; $\left.76.00 \pm 1.15, \mathrm{~T}_{3} ; 75.02 \pm 1.08\right)$ at 45 days rearing period. Slightly higher protein content $(17.48 \pm 0.28)$ was calculated in stinging catfish at the 45th day fed with live tubificid worms. There were no significant differences among the treatments conducted.

Moisture content of shingi ranged between 75.05 and $76.50 \%$. Rahman et al., (1982) in another study dealing with the amount of moisture, fat and protein in fish reported that general fish contains 70-80\% moisture. Thus, moisture content in present study is in a good agreement with the values reported in the previous studies (Rahman et al., 1982; Rubbi et al., 1987; and Siddiqui and Choudhury, 1996). In a previ-

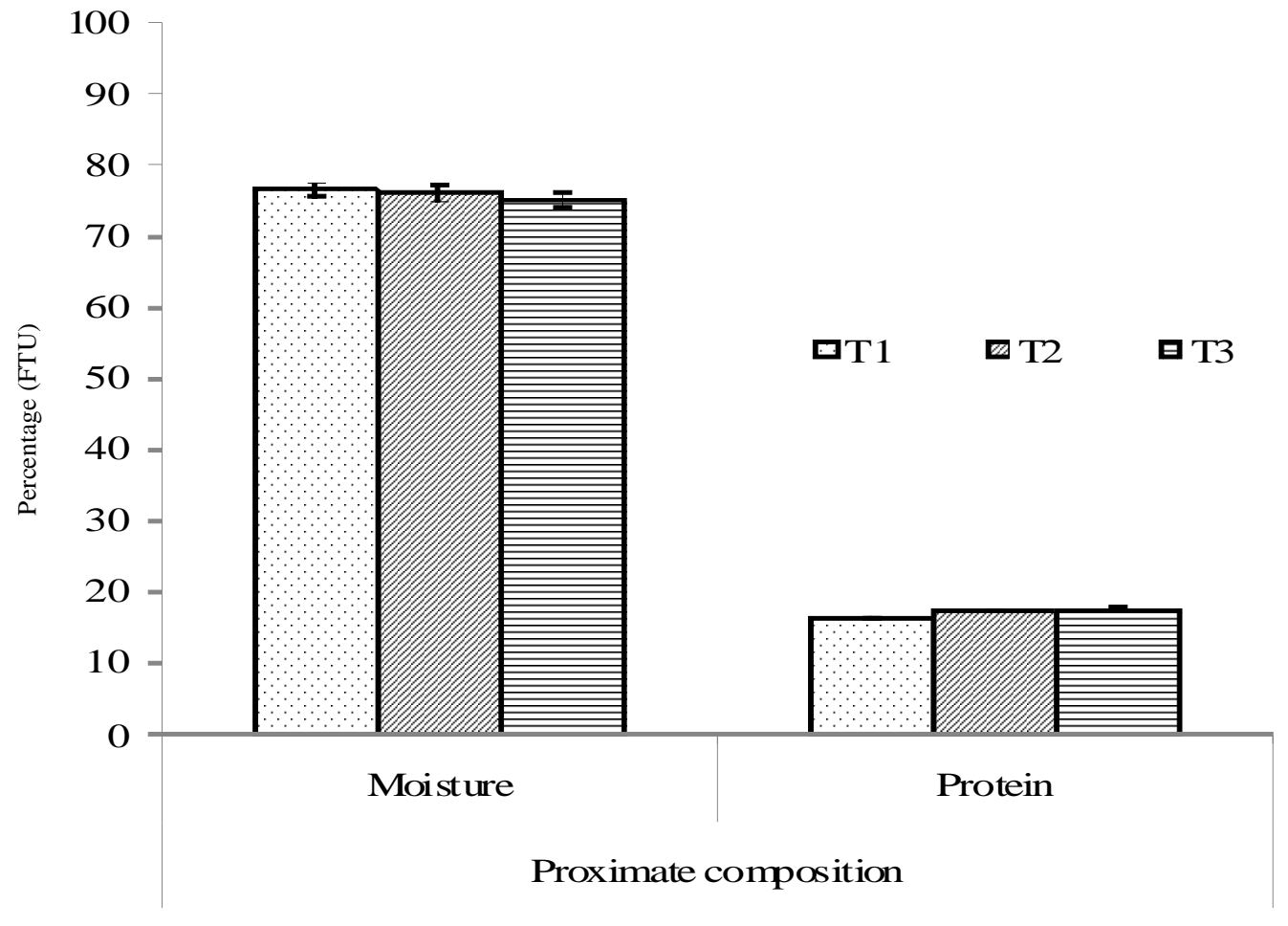

Fig. 7. Proximate composition (\%) of stinging catfish at the 45th day of rearing period. No significant difference was found within the treatments 
ous study (Dresoier, 1977), protein content in fish was reported to be in a range of $13-20 \%$. In another study (INFS, 1983), protein content of freshwater fish was estimated to be $15-18 \%$.

Our findings suggest that use of live feed tubificid worms in rearing stinging catfish could be a suitable technique for facing problems during culture period and might be helpful in protecting one of the threatened catfish in Bangladesh.

\section{Acknowledgement}

The research work was funded by the University Grants Commission (UGC), Bangladesh in the financial year 2014.

\section{References}

Akand AM, Miah MJ and Haque MM (1989), Effects of dietary protein level on growth, feed conversion and body composition of shingi (Heteropneustes fossilis Bloch). Aquaculture 77: 175-180.

AOAC (1995). Official Methods of Analysis of AOAC International, $16^{\text {th }}$ Ed. Association of official Analytical Chemists, Washington DC.

Chakraborty BK and Mirza JA (2008). Growth and yield performance of threatened singi, Heteropneustes fossilis (Bloch) under semi intensive aquaculture. J Fish Soc Taiwan 35: 117-125.

Dehadrai PV, Kamal MY and Das KK (1985), Package of practices for increasing production of air- breathing fishes. In: Aquaculture Extension Manual No. 3:1-14. Central Inland Fisheries Research Institute, Barrackpore.

Dresoier NW (1977), Element of food technology. The Avi Publication Company Incorporation, pp. 384.

Haque MM, Alam AKMN and Islam MA (1988), Culture prospects of shying (Heteropneustes fossilis) in floating cages, Bangladesh J Fisheries 12: 67-72.
Hossain A, Mollah FMA and Hasan M (2012), Ratio Optimisation of Media Ingredients for Mass Culture of Tubificid Worms (Oligochaeta, Tubificidae) in Bangladesh. Asian Fisheries Sci 25: 357-368.

INFS (1983), Nutritional Survey of Rural Bangladesh, 198182. University of Dhaka. Dhaka.

IUCN (2000). Red book of threatened fish of Bangladesh. The world Conservation Union. Appendix 1, $61 \mathrm{p}$.

Khan MN, Islam AKMS and Hussain MG (2003), Marginal analysis of culture of stinging catfish (Heteropneustes fossilis): Effect of different stocking density in earthen ponds. Pak J Biol Sci 6: 666-670.

Kohinoor AHM, Khan MM, Yeasmine S, Mandol P and Islam MS (2012), Effects of stocking density on growth and production performance of indigenous stinging catfish, Heteropneustes fossilis (Bloch). Int $J$ Agricult Res Innov Technol 2: 9-14.

Lietz DM (1987), Potential for aquatic oligochaetes as live food in commercial aquaculture, Hydrobiologia 155: 309-310.

Medawar PB (1945), Size, shape and age. In: Essays on growth and form: presented to D'Arcy Wentworth Thompson (eds W.E. Le Gros Clark and P.B. Medawar), Clarendon Press, Oxford.

Mollah MFA (1985), Effects of stocking density and water depth on the growth and survival of freshwater catfish (Clarias macrocephalus Gunther) Larvae. Indian J Fisheries 32: 1-17.

Narejo NT, Salam MA, Sabur MA and Rahmatullah SM (2005). Effect of stocking density on growth and survival of indigenous catfish, Heteropneustes fossilis (Bloch) reared in cemented cistern fed on formulated feed, Pak J Zool 37: 49-52. 
Rahman MA, Gheyasuddin H, Rasid MH and Choudhury MFZ (1982), Proximate composition and native quality of freshwater Zeol fishes of Bangladesh. Bangladesh J Fisheries 25: 37-43.

Rubbi SF, Mujibar M, Khan AR, Jahan SS and Majeda B (1987), Proximate composition and quality of some commercial species of fresh water fish. Bangladesh $J$ Sci Res 5: 1-20.

Siddiqui K and Choudhury SN (1996), In: Matsya-Pukure Match Chash Manual (A Manual on Pond Pisciculture) Institute of Local Government, Agargaon, SherBanglanagar, Bangladesh.
Singh BN and Hughes GM (1971), Respiration in an airbreathing catfish, Clarias batrachus. J Exp Biol 55: 421-434.

Received: 02 March 2016; Revised: 13 March 2016; Accepted:24 April 2016. 